Acta Regionalia et Environmentalica 1

Nitra, Slovaca Universitas Agriculturae Nitriae, 2017, pp. 1-6

\title{
IS RURAL TOURISM A PERSPECTIVE DRIVER OF DEVELOPMENT OF RURAL MUNICIPALITIES? - THE CASE OF SLOVAK REPUBLIC
}

\author{
Katarína MELICHOVÁ*, L’ubica MAJSTRÍKOVÁ \\ Slovak University of Agriculture in Nitra, Slovak Republic
}

\begin{abstract}
Importance of rural tourism as a specific form of tourism lies primarily in its potential to be a driving force for the development of rural municipalities and diversify their economic base. The aim of this paper is to verify this assumption, while analysing the relationship between the concentration of tourism activities and migration trends in rural municipalities in Slovakia. The results support the claim that tourism has significant positive effects manifested by a positive migration balance in municipalities where the tourism industry has a significant presence. The relationship between the level of net migration and rural tourism localisation index in rural areas is not entirely clear because of high diversity of rural municipalities. It is true that in the "catchingup" group of rural municipalities, where the previously negative trend of migration turned positive, localisation index of rural tourism reaches a peak, which may suggest that precisely this sector could be the driver of this positive development. On the other hand, there is a group of marginalized rural municipalities where the concentration of rural tourism industry measured by the index of localisation is also relatively high, but nevertheless, these municipalities suffer from a loss of population due to outmigration.
\end{abstract}

Keywords: rural tourism effects, rural municipalities, migration, development driver

Rural regions and municipalities are currently facing many challenges. Among the causes of rural problems are deepening imbalance in spatial development due to trends of capital concentration in urban areas brought by agglomeration effects and insufficient use of available natural and human resources located in rural areas that could potentially contribute more to the economic development of the country (Belajová, 2006). Based on these problems, Jarábková (2010) suggests one possible solution - the concept of endogenous development based on the use of internal resources of rural municipalities, support of small and medium enterprises and establishment of partnerships between public and private sector. Yet, in the Slovak reality, during the decision making about the strategic development of territory, the private sector is often underrepresented (Bumbalová et al., 2016).

Rural development should be sustainable and achieve local and regional harmony through optimally balanced spatial and functional use of that potential. A key condition for activating the development potential of rural space is synergy. An important factor influencing the sustainable rural development is the interaction between ecosystems, production processes, goods and services, local supply chains and ultimately within specific and changing social environments (Fáziková, 2013). From this stems the changing position of agriculture which is not a core industry any longer, with other activities taking the lead that bring a variety of benefits for the population in rural areas.
Buchta (2012) noted that sustainability of economic life in rural areas is still influenced by the presence of agriculture and its economic performance. Despite the decline in the importance of agriculture in rural areas, agricultural activities employ significant portion of (especially local) workforce in the rural economy. Another benefits of agriculture are the preservation and maintenance of natural resources and a suitable area for the development of rural tourism. As Gannon (1994) further states, these resources could be mobilised to aid rural communities in transition processes from typically agrarian to more diversified and thusly more sustainable economies.

Mose (2007) summarized several factors that influence the spatial development of individual rural areas, such as diversification into non-agricultural activities - agricultural businesses are looking for alternative sources of income, among which we can include rural tourism, or specifically agritourism. This form of diversification of economic activity is typical in particular for small and medium-sized enterprises, which can adapt easier to market demands and recreation and leisure possibilities - many rural areas began to multiply recreational and tourist offers relatively quickly, and in some these are often the only economical alternatives to agriculture. Fleischer and Felsenstein (2000), using the cost-benefit analysis of public support programs aimed at small-scale tourism enterprises in Israel found that these programs in rural areas generated greater returns than 
the same programs aimed at other enterprises of similar size but operating in different sectors.

Tourism is characterized as one of the fastest growing sectors of the economy, particularly in respect of revenue (in 2014 global revenues from tourism reached 1,159 bil. US\$ and $9 \%$ of GDP) and jobs that it generates (according to UNWTO, in 2014 tourism created one in 11 jobs) (UNWTO Tourism Highlights, 2016).

Borovský, Smolková and Niňajová (2008) states that the positive impact of tourism on the economy of the country is reflected in a number of ways, such as impact on GDP, employment, economic restructuring, stimulating new business activity, foreign trade balance, training, development of IT and communication infrastructure, transportation, legislation, culture, environment, rural development, promotion of small and medium enterprises, development of new interregional activities, vitality and health, cooperation between state and local governments, international relations, etc.

But not all rural areas have necessary prerequisites for development of tourism. Mostly smaller mountain regions are more popular as tourist destinations than regions of high intensity of agricultural activity over large areas. Citing these facts as well as various empirical studies conducted in European countries, Cánoves et al. (2004) criticise the approach to rural tourism as a "cure-all" solution for the problems that rural communities and economies face in the modern globalised society.

Rural regions and municipalities of the Slovak Republic are currently facing many challenges. Countryside of Slovakia, typically agriculturally oriented, has undergone many changes in past couple of decades. Increasing mechanization of agricultural production decreased demand for labour, thus increasing the burden on the diversification of rural economy. The contribution of rural tourism in this context relates closely to the effect of employment.

Other problem of rural municipalities and regions is demographic decline mainly due to the emigration of the population from rural areas, leading to their depopulation. Providing job opportunities could be one of the most important ways that rural tourism industry could help in maintaining economically active population in rural areas.

Regarding the potential of market and product development in rural tourism sector in post-communist central and eastern European countries, Hall (2004) stresses the importance and impact of the EU membership. However, the author further states that this positive impact may be hampered due to lower quality of human capital in these countries (lack of necessary skills, knowledge base and training opportunities to acquire them) as well as generally low level of collaborative and networking efforts in promotion and marketing of the local rural tourism products. Bramwell (1994) reiterates this position implying that stronger focus should be given to the role of local stakeholders (both communities as well as businesses) and to their collaboration in shaping rural tourism as opposed to relying on uncontrollable exogenous forces.

\section{Material and methods}

Importance of rural tourism as a specific form of tourism lies primarily in its potential to be a driving force for the development of rural regions and municipalities and for diversification of their economic base. The aim of this paper is to verify this assumption, while investigating the relationship between the concentration of tourism activities and migration trends in rural municipalities in Slovakia.

Given the high annual variability of net migration at the local level, we decided to use the classification of municipalities of Slovakia in the context of development categories proposed by Melichová (2016), which are based on the value of net migration in two periods 2005-2009 and 2010-2014 and classified into four types of municipalities: leading $(+/+)$, catching-up $(-/+)$, stagnating (+/-) and lagging (-/-).

The method presented above has been chosen in the absence of other indicators that we could use to quantify the level of development at the local level. Therefore we start from the assumption that the manifestation of a developing municipality is also the increase of number of its inhabitants.

The concentration of rural tourism activities at the local level was quantified using localisation index of core rural tourism activities.

$I L_{i}^{R T}$ - localisation index for rural tourism in the $i$-th municipality, calculated as follows:

$$
I L_{i}^{R T}=\frac{X_{r t_{-} i} / X_{r t}}{I_{i} / I}
$$

where:

$X_{r t \_i}-$ number of rural tourism entities in $i$-th municipality

$X_{r t}^{r t} \quad-$ number of rural tourism entities in Slovakia

$I_{i}^{r t} \quad-$ number of inhabitants in $i$-th municipality

I - number of inhabitants in Slovakia

The number of entities was used, despite the fact that this method is generally based on the use of employment data, or the production volume, in order to avoid a significant skewing of results. As reported by Melichová and Fáziková (2014), in the case where the sector is dominated by large number of micro and small enterprises in terms of number of employees, employment figures are not an appropriate indicator, since in the Slovak Republic at the district level those are reported only for enterprises with 20 and more employees. This approach would exclude data for businesses that are typical for the rural tourism sector.

Another reason for the application of this correction to the established methodology is the need to obtain information about the location of these entities at the municipal level, since rural tourism sector is defined based on the spatial principle - which means that rural tourism activities are considered tourism activities located in rural municipalities.

Due to all these circumstances, the use of number of entities instead of employment data is a necessary correction of the proposed methods. Therefore, we will 
Table 1

Core and supporting economic activities in the tourism sector

\begin{tabular}{|c|c|}
\hline Rural Tourism Core Activities & Rural Tourism Support Activities \\
\hline (according to main classification) & (according to main classification) \\
\hline 55100 Hotels and similar accommodation & 49100 Passenger rail transport, interurban \\
\hline 55200 Holiday and other short-stay accommodation & 49310 Urban and suburban passenger land transport \\
\hline 55300 Camping grounds, recreational vehicle parks and trailer parks & 49320 Taxi operation \\
\hline 55909 Other accommodation & 49390 Other passenger land transport n.e.c \\
\hline 56109 Restaurants and mobile food service activities & 50100 Sea and coastal passenger water transport \\
\hline 56210 Event catering activities & 50300 Inland passenger water transport \\
\hline 56290 Other food service activities & 51100 Passenger air transport \\
\hline 56300 Beverage serving activities & 63990 Other information service activities n.e.c. \\
\hline (according to secondary classification) & 79110 Travel agency activities \\
\hline \multirow{3}{*}{$\begin{array}{l}\text { Economic activities under division codes: } \\
01 \text { Crop and animal production, hunting and related service } \\
\text { activities } \\
03 \text { Fishing and aquaculture } \\
10 \text { Manufacture of food products } \\
11 \text { Manufacture of beverages } \\
\text { which in addition to main activities report at least one economic } \\
\text { activity under codes pertaining to the core tourism activities }\end{array}$} & 79120 Tour operator activities \\
\hline & $\begin{array}{l}91030 \text { Operation of historical sites and buildings and similar } \\
\text { visitor attractions }\end{array}$ \\
\hline & $\begin{array}{l}91040 \text { Botanical and zoological gardens and nature reserves } \\
\text { activities }\end{array}$ \\
\hline
\end{tabular}

Source: own elaboration based on the Classification of economic activities SK NACE Rev. 2 Statistical Office of the Slovak Republic, 2014

rely on the registry of organizations, which includes all relevant information on businesses as well as other entities. To account for a certain amount of the loss of information when using this approach, the number of entities in individual municipalities will be weighted using weights calculated based on classification of entities into size categories according to the number of employees. Entity specific weight was set as a middle value of the interval of their size class.

The relationship between the two variables was investigated using the application of non-parametric Kruskal-Wallis test for analysis of variance. The use of this method is contingent on the violation of normality assumption caused by occurrence of extreme values in localisation index at the local level, since the test is robust to the presence of extreme values. However, the application of the test requires equality of variance in four defined groups of municipalities (homoscedasticity), which was tested with Leven test and has been confirmed. The statistical software used is Statgraphics.

The following subclasses of the SK NACE classification at the four-digit code level were included as economic activities of the rural tourism sector (Table 1).
Economic entities of various sectors of agriculture, fisheries and manufacturing industries, were included in the sectoral classification of rural tourism due to the fact that a typical feature for several forms of rural tourism, mainly agritourism, is precisely the fact that those entities usually operate under different main activity, primarily agricultural production, but also maintain secondary activities, the nature of which affiliates them with rural tourism sector.

\section{Results and discussion}

As noted in the previous chapter, specific quantification of the effect of rural tourism industry on development of rural communities is difficult. Not only due to the fact that it is difficult to get useful data for meaningful analysis with sufficient explanatory power on local level, but also due to the very wide range of impacts that these activities can have on local communities. Some are of qualitative nature, others are indirect, i.e. induced and the dependence between them and rural tourism activities can be difficult to establish. In this part of the paper, we examine the

Table 2 The results of the Kruskal-Wallis test of weighted localisation index of rural tourism core activities

\begin{tabular}{|l||c|c|}
\hline Development type of municipalities & Sample size/number of municipalities & Average Rank \\
\hline \hline (1) Leading +/+ & 444 & $1,244.43$ \\
\hline (2) Catching-up -/+ & 1,338 & $1,484.52$ \\
\hline (3) Stagnating +/- & 464 & $1,218.43$ \\
\hline (4) Lagging -/- & 508 & $1,357.21$ \\
\hline
\end{tabular}

Source: own elaboration

Test statistic $-57.3639 ; P$-value $-2.14906 \mathrm{E}-12$ 


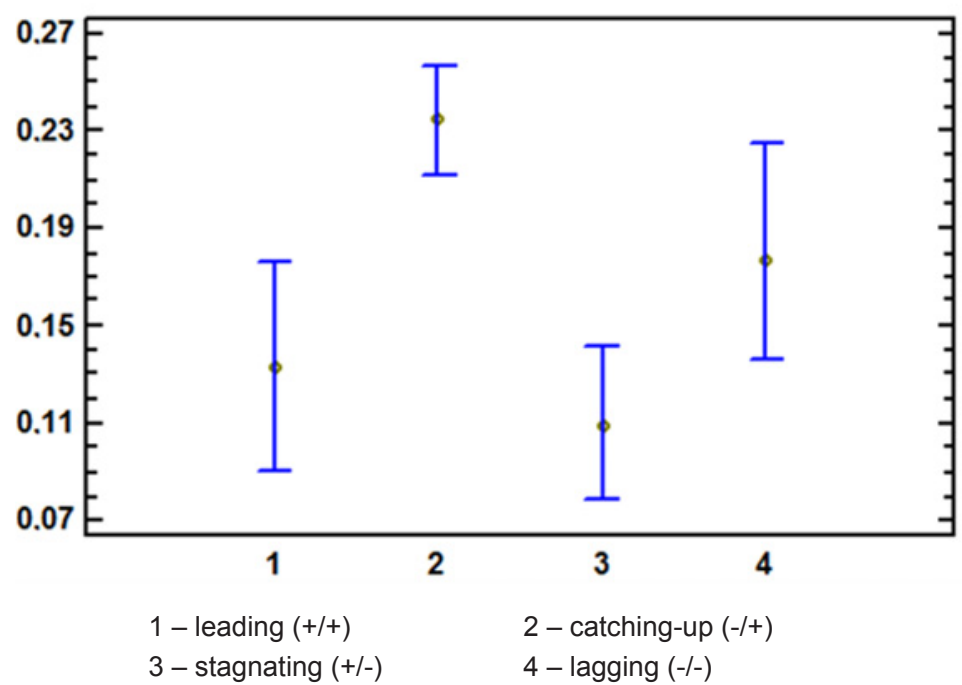

Figure 1 Comparison of medians of weighted localisation index of rural tourism activities in different development types of rural municipalities in Slovakia (2014)

Source: own elaboration

difference in the concentration of activities of rural tourism between the four development types of rural municipalities in the Slovak Republic.

Since the test statistic of the KruskalWallis test was shown to be statistically significant ( $p$-value is less than 0.05), we conclude that there are significant differences in the localisation index of core tourism activities in the four defined development types of rural municipalities. The highest value of the average ranking in terms of concentration of rural tourism activities is characteristic for the largest group of rural municipalities, those whose development trajectory took a positive turn in the last five years. However, to comprehensively assess the way the tourism industry concentration may affect rural development, we further compare the differences between specific categories.

A surprising finding is that a set of rural municipalities that belong to the first category is characterized by a relatively lower concentration of rural tourism industry. It indicates the presence of other development factors, or competitive advantages, which serve as a basis for the development of these municipalities. The relatively highest concentration of rural tourism was identified in the "catching-up" rural municipalities. These are the municipalities that have started to achieve positive net migration in the second time period. An important finding is the fact that it is precisely this category of municipalities that not only has the highest index value of localisation of rural tourism, but also the lowest variability of these values compared to other categories. On the other hand, stagnant rural municipalities are characterized by the lowest concentration of rural tourism sector.

If we compare the situation in the catching-up and stagnating rural municipalities, we can conclude that rural tourism could be the key factor determining why the formerly lagging municipalities reached higher level of development in the period 2010-2014, while the populations of rural municipalities, which had positive net migration in the first time period started to decrease. In the first category of municipalities, the sector of rural tourism can create jobs and thus prevent migration of population. Stagnant municipalities could have lost their positive standing by failing to diversify their economic base in the aftermath of the fall in employment in the agricultural sector, thereby resulting in reduction of the number of jobs and increase of the outflow of population. Catching-up and stagnating rural municipalities are not only characterized by a maximum of difference in concentration of rural tourism industry, but also diametrically opposed direction of development.

The second highest concentration of rural tourism industry was identified in lagging rural municipalities. Given that previous findings suggest that rural tourism can be an important driver of development of (even previously declining) rural municipalities, this is a surprising result. In order to investigate the reasons for this situation and due to the high variability in values of localisation index in rural municipalities within this group, we decided to examine the concentration of rural tourism industry in the context of size of different development types of rural municipalities.

It is significant that in leading and catching-up types of municipalities, rural tourism has a strong position especially in large municipalities with more than 2,000 inhabitants. In the category of lagging rural municipalities, it is clear that the highest concentration of rural tourism industry is characteristic for the

Table 3 Average localisation index of rural tourism activities according to the size and development type of rural municipality (2014)

\begin{tabular}{|l||c|c|c|c|c|}
\hline Development type /Size type & Leading (1) & Catching-up (2) & Stagnating (3) & Lagging (4) & Total \\
\hline \hline up to 499 inhab. & 0.511765 & 0.525792 & 0.701631 & 0.685262 & 0.592453 \\
\hline $\mathbf{5 0 0 - 1 , 9 9 9}$ inhab. & 0.457384 & 0.709345 & 0.649388 & 0.667352 & 0.664202 \\
\hline $\mathbf{2 , 0 0 0 - 5 , 0 0 0 ~ i n h a b . ~}$ & 0.873072 & 0.897166 & 0.766742 & 0.581717 & 0.819318 \\
\hline Total & 0.530905 & 0.672522 & 0.684254 & 0.665386 & 0.650351 \\
\hline
\end{tabular}

Source: own elaboration 
smallest municipalities and municipalities with the number of inhabitants lower than 2,000. We can therefore assume that the reason why this sector does not produce positive effects like the ones in other municipalities, despite good localisation conditions for development of rural tourism, is that they lack a sufficient concentration of resources, especially human capital, which is required for the effective exploitation of external resources supporting the development of this sector as a source of growth. However, for a comprehensive understanding of this phenomenon it is necessary to locate more precisely the specific lagging municipalities in question. The last development type of municipalities consists mainly of municipalities in the Košice, Prešov and Banská Bystrica regions (e.g. in the districts of Rožňava, Trebišov, Svidník, Vranov, Bardejov, Rimavská Sobota and others). Therefore, they are mostly located in remote regions less accessible given the lower level of transport infrastructure. This could negatively affect the potential of rural tourism as a driver for the development of these municipalities from the demand side.

\section{Conclusion}

One particular purpose of policies promoting rural tourism is solving the problems of rural municipalities and rural areas, mainly resulting from a change in the position of agriculture in rural areas, which is accompanied by a decline of employment in this sector. In the context of other problems of rural municipalities and regions, such as insufficient infrastructure development, fragmented settlement structure and related low potential for employment and limited access to markets, causing the depopulation of rural communities and weakening of their economic base while becoming more dependent on urban economies.

In this context, we formulated the research question whether the sector of rural tourism has positive effects on rural municipalities in Slovakia. The answer is yes - it has significant positive effects manifested by a positive migration balance in the municipalities where the tourism industry has a significant presence. The relationship between the level of net migration and localisation index of rural tourism activities in rural areas is not entirely straightforward given the high diversity of rural municipalities. It is true that the so-called "catching-up" group of rural municipalities where previously negative trend of migration turned positive localisation index of rural tourism activities reaches a peak, which may suggest that it is precisely this sector that could be one of the generators of this positive development.

On the other hand, there is a group of lagging and marginalized rural municipalities where the concentration of rural tourism industry measured by the index of localisation is also relatively high, but nevertheless, these municipalities suffer from a loss of population due to outmigration. Explanation of this paradox lies in the fact that rural tourism has the highest potential for development in communities that are located near bigger cities. The target group of rural tourism businesses is mainly domestic clientele coming from the big cities. Changing preferences of the population in connection with leisure and relaxation activities support the higher rate of visits in facilities near major cities.

Okech et al. (2012) list several other factors that determine the success of rural tourism sectors, namely the quality of the products and services, accessibility and the infrastructure of the destination, availability of skills, and the interest of investors. Unfavourable impact of these factors seems to explain the absence of positive effects of rural tourism activities in least developed and lagging regions and municipalities in Slovakia as well.

Underdevelopment of rural tourism sector in some regions could be also explained by relative recentness of policies aimed at promoting rural tourism activities in Slovakia; a factor that Cánoves et al. (2004) used to explain the differences between the level of development of rural tourism sector and its impacts in Spain and other advanced economies in Europe, stating that as a result, there are considerable spatial disparities and fragmentation of commercialisation and marketing activities.

Possible solutions to these problems can be found in the works of several authors. Hanáčková and Bumbalová (2016) state that innovation processes in local selfgovernments as important development actors play a crucial role in developing and strengthening partnerships and networks with various other relevant players in many aspects as well as in the increasing of effectiveness of their functioning, bringing synergetic effects. Chreneková et al. (2016) go one step further and promote social entrepreneurship as a way to increase the quality of life in rural areas, producing and providing such services that satisfy needs of the community, while using available resources, which are not valorised by the private sector due to the lower level of economic effectiveness. The potential of social entrepreneurship in rural tourism in Slovak conditions is further substantiated by the facts that according to the authors, in 2016, 31\% of all social enterprises in the Slovak Republic either provided accommodation and restaurant services or operated in the cultural industries sectors.

\section{Acknowledgments}

The paper has been elaborated as an output of the project VEGA No. 1/0247/14 Integrated approaches to development of rural tourism in Slovakia.

\section{References}

BELAJOVÁ, A. 2006. Štrukturálne zmeny na slovenskom vidieku. In Venkov je náš svět. Sborník príspevků z mezinárodní konference. Český Krumlov : Česká zemědelská univerzita,. pp. 288-294. ISBN 80-213-1539-3.

BOROVSKÝ, J. - SMOLKOVÁ, E. - NIŇAJOVÁ, I. 2008. Cestovný ruch: trendy a perspektívy. 1. ed. Bratislava : lura Edition. ISBN 978-80-8078-215-3.

BRAMWELL, B. 1994. Rural tourism and sustainable rural development. In Journal of Sustainable Tourism, Vol. 2, No. 1-2, pp. 1-6. DOI: http://dx.doi.org/10.1080/09669589409510679.

BUCHTA, S. 2012. Vývojové trendy vidieckych a mestských oblastí Slovenska. In Economics of Agriculture, vol. 12, no. 4, pp. 1-20.

BUMBALOVÁ, M., TAKÁČ, I., VALACH, M., TVRDOŇOVÁ, J., (2016). Leader - Ex-Post Evaluation of the Delivery Mechanism. In European 
Countryside, vol. 8, no. 2, pp. 160-174. DOI: https://doi.org/10.1515/ eual-2015-0002.

CÁNOVES G., VILLARINO M., PRIESTLEY G.K., BLANCO, A. 2004. Rural tourism in Spain: an analysis of recent evolution. In Geoforum, vol. 35, no. 1, pp. 755-769. DOI:10.1016/j.geoforum.2004.03.005.

FÁZIKOVÁ, M. 2013. Pojem vidiek, jeho definícia a typológia. [online] Nitra : SPU, 2013. 24 p. Study material for the course 314 U501 Rural Development. [[Retrieved 2016-03-16]. Retrieved from: $<$ https://is.uniag.sk/auth/dok_server/slozka.pl?id=7205;down load $=6662$;lang $=$ sk $>$

FLEISCHER, A., FELSENSTEIN, D. 2000. Support for Rural Tourism Does it Make a Difference? In Annals of Tourism Research, vol. 27, no. 4, pp. 1007-1024.

GANNON, A. 1994. Rural tourism as a factor in rural community economic development for economies in transition. In Journal of Sustainable Tourism, Vol. 2, No. 1-2, pp. 51-60. DOI: http://dx.doi. org/10.1080/09669589409510683.

HALL, D. 2004. Rural tourism development in south-eastern Europe: transition and the search for sustainability. In International Journal of Tourism Research, Vol. 6, No. 3, pp. 165-176. DOI: 10.1002/jtr.482.

HANÁČKOVÁ, D., BUMBALOVÁ, M. 2016. Inovácie v samospráve. In Acta Oeconomica Universitatis Selye, Vol. 5, No. 2, pp. 88-96. ISSN1338-6581.
CHRENEKOVÁ, M., JARÁBKOVÁ, J., GUBÁÑOVÁ, M. 2016. Sociálne podnikanie $v$ cestovnom ruchu. In Acta Oeconomica Universitatis Selye, Vol. 5, No. 2, pp. 97-108. ISSN1338-6581.

JARÁBKOVÁ, J. 2010. Vidiek - nevyužitý potenciál pre vidiecky cestovný ruch. Nitra : Slovak University of Agriculture in Nitra. ISBN 978-80-552-0364-5.

MELICHOVÁ, K. -- FÁZIKOVÁ, M. 2014. Creative clusters in rural areas - a case study from Slovakia. In XVII. Mezinárodní kolokvium o regionálních vědách. Brno : Masarykova univerzita, pp. 134-142. ISBN 978-80-210-6840-7.

MELICHOVÁ, K. 2016. The final report on the project VEGA 1/0685/13 Development drivers of rural regions.

MOSE, I. 2007. Protected Areas and Regional Development in Europe: Towards a New Model for the $21^{\text {st }}$ century. Cornwall : MPG Book Ltd., Bodmin. ISBN 978-0-7546-4801-7.

OKECH, R., HAGHIRI, M., GEORGE, B.P. 2012. Rural Tourism as a Sustainable Development Alternative: An Analysis with Special Reference to Luanda, Kenya. In Cultur Special Issue: Sustainability, Tourism \& Environment in the Shift Of a Millennium: A Peripheral View, Vol. 6, No. 3, pp. 36-54.

UNWTO. 2016. Tourism Highlights. Madrid : World Tourism Organization. ISBN 978-92-844-1689-9. 